\title{
Kinetic Studies of Adsorption of Heavy Metals on Clays
}

\author{
O. Olaofe ${ }^{1}$, S. A. Olagboye ${ }^{1}$, P. S. Akanji ${ }^{1}$, E. Y. Adamolugbe ${ }^{1}$, O. T. Fowowe ${ }^{1}$, \& A. A. Olaniyi ${ }^{1}$ \\ ${ }^{1}$ Department of Chemistry, Ekiti State University, Nigeria \\ Correspondence: S. A. Olagboye, Department of Chemistry, Ekiti State University, Ado-Ekiti, Nigeria. E-mail: \\ olagboyesa2009@yahoo.com.
}

\author{
Received: August 8, 2014 Accepted: October 10, 2014 Online Published: December 29, 2014 \\ doi:10.5539/ijc.v7n1p48 URL: http://dx.doi.org/10.5539/ijc.v7n1p48
}

\begin{abstract}
Kinetic studies of adsorption of heavy metals ( $\mathrm{Pb}$ (II), $\mathrm{Cu}(\mathrm{II}), \mathrm{Cd}(\mathrm{II})$ and $\mathrm{Zn}$ (II)) on local clay soils from four different locations in Ekiti state have been studied using static batch experimental method. The major factors affecting the heavy metal ions sorption on local clays were investigated. The experimental data were correlated with adsorption isotherm and kinetic equations using linear regression analysis. The plots of the amount of adsorbate adsorbed against equilibrium concentration or mass of dosage of clay or time showed two distinct segments. Firstly, nearly a straight line plot at low concentration and secondly a flat or plateau portion at high concentration were observed. The monolayer concentration of the adsorbent was calculated. Langmuir isotherm was found to correlate the adsorption data better than the Freundlich isotherm. The parameters in these isotherms were evaluated and fully discussed. The adsorption kinetic data were correlated with three functions. The Olaofe proposed function $\left(\mathrm{R}^{2}=97.5-99.0 \%\right)$ was found to be the best followed by Simple Elovich function $\left(\mathrm{R}^{2}=84.5-\right.$ $95.9 \%)$ and the least was the power function $\left(\mathrm{R}^{2}=84.3-93.1 \%\right)$.The parameters in the functions and statistical data were reported and fully discussed. The present report has shown that local raw Nigerian clays can be used as adsorbents.
\end{abstract}

Keywords: Adsorption, kinetic studies, clays, heavy metals, isotherm

\section{Symbols}

\begin{tabular}{|c|c|}
\hline A & power function constant \\
\hline B & power function constant $\quad(\mathrm{mol} / \mathrm{dm} 3 . \mathrm{g} . \mathrm{sec})$ \\
\hline $\mathrm{C}$ & concentration of adsorbate adsorbed (mol/dm3.g.sec) \\
\hline Cads & concentration of adsorbent adsorbed (mol/dm3.g.sec) \\
\hline $\mathrm{d}$ & simple Elovich constant (mol/dm3.g.sec) \\
\hline DV & $\%$ deviation \\
\hline $\mathrm{K}_{\mathrm{L}}$ & Langmuir adsorption equilibrium constant $\left(\mathrm{dm}^{3} \mathrm{~mol}^{-1}\right)$ \\
\hline $\mathrm{k}_{\mathrm{f}}$ & Freundlich isotherm constant. mol ${ }^{(1-1 / n)} \cdot\left(\mathrm{dm}^{3}\right)^{(1 / n-1)} / g$ \\
\hline K1 & Olaofe equilibrium constants (mol/dm3.g.sec) \\
\hline $\mathrm{K} 2$ & Olaofe equilibrium constants (mol/dm3.g.sec) \\
\hline n & Freundlich constant (no unit) \\
\hline $\mathrm{R}$ & R-square $(\%)$ \\
\hline 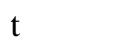 & time $(\mathrm{sec})$ \\
\hline Vads. & Concentration of adsorbate adsorbed (mol/dm3.g.sec) \\
\hline max. & Monolayer adsorption of the adsorbate on the adsorbent (mol/dm3.g.sec) \\
\hline
\end{tabular}

\section{Introduction}

Excessive release of heavy metals into the environment due to industrialization and urbanization has posed a great problem worldwide. Presently, with the rapidly increasing urban population, heavy metals become contaminants of concern in waters. There is a strong need to reconsider the consumption of water to ensure that it is free of pollution. Organic pollutants are susceptible to biological degradation while heavy metals or ions do 
not degrade into harmless products $(\mathrm{Yu}, 2005)$. The presence of heavy metal ions, is a major concern due to their toxicity to many life forms. Conventional methods for removing heavy metals from aqueous solutions include chemical precipitation, ion exchange, adsorption (Gode and Pehlivan,2006) and membrane filtration technologies. Of all these methods, adsorption method is simple and relatively cost- effective. Bio-sorption is a promising techniques for the adsorption of heavy metals from aqueous environments especially when adsorbents are derived from lignocelluloses carbonaceous materials, natural resources, plant wastes, agricultural wastes (Orhan and Buyukgungar, 1993; Coelho et al.,2001; Babarinde, 2002; Muranoon and Sastre,1999; Olaofe and Bosch1980).

Due to the toxicological importance in the ecosystem, agriculture and human health, pollution by heavy metals has received wide spread attention in the recent years. Copper, an element or its ions, which has been used by man for years, can be regarded as a long standing environmental contaminant (Abd El-Gaffar et al., 2012). During the last decades, the process of adsorption using activated carbon from agricultural wastes has been found to be an efficient technology for the removal of copper(II), zinc(II),lead(II) and cadmium(II) from waste water (Saikia et al.,1987; Wilczak et al., 1993; Chao-Yin, 2009; Hengpeng et al.,2012)

The term clay or clay mineral is usually applied to earthly neutral materials in which more than $70 \%$ of the constituents are either made up of clay minerals with particles smaller than $0.002 \mathrm{~mm}$. Clay soil impels the flow of water and then retains it for a longtime. On addition of water, clay soil becomes heavy, sticky and increase in volume (Guggenhein et al., 1995). Bentonile is a group of clay soil, which is used in foundry work and in the preparation of the mould for casting metals. Bentonile is used in industries as filtering and deodorizing agent, refining of petroleum, dressing in construction, clarifying water and wine and purifying sewage (Hiller et al., 2003; Scarre,2005).

Clay exhibits plasticity when mixed with water in certain proportions, The physical and chemical properties of clay drastically change when fired in a kiln. These changes will cause the clay to be converted into a ceramic material (Scarre, 2005).

Clays are distinguished from other fine-grained soils by differences in size and mineralogy, clay is finer than silts. Geologist and soil scientists usually consider the separation at a particle size of $2 \mu \mathrm{m}$, while sedimentologists often use 4-5 $\mu \mathrm{m}$ and colloid chemists use $1 \mu \mathrm{m}$ (Guggenhein., et al, 1995). With respect to the widely used adsorption method for the removal of heavy metals in aqueous systems, clay minerals have a great potentiality to adsorb pollutant due to their large specific surface area. Chemical and mechanical stability, layered structure and high cation exchange capacity, it is expected that clay would be a very good adsorbent (Bhattachagyya Gupta, 2008; Eloussaief and Benzina, 2012) The present study therefore investigates the adsorption capacity of local clays using heavy metals $(\mathrm{Pb}, \mathrm{Zn}, \mathrm{Cu}$ and $\mathrm{Cd})$. These metals are toxic and highly detrimental to health at elevated concentrations.

Adsorption process has been found to be significantly depended on $\mathrm{pH}$, contact time, particle size, mass of adsorbent, concentration of adsorbate and others. The adsorption behaviour would be fully represented by Langmuir and Freundlich adsorption isotherms in the present study. The kinetic of adsorption has been also investigated using three kinetic equations namely power function, simple Elovich and Olaofe proposed equations.

\section{Materials and Methods}

Clay soils from different locations: Ara-Ekiti (CA), Ipetu-Ijesa (CP), Araromi-Obo (CAO) and Are-Afao Ekiti (CAA). Samples were collected, sun dried for seven days in order to remove moisture from the soil samples. The particle size was reduced using a milling machine and sieved using meshes of different apertures in order to determine the mean particle size. Each of the sample sizes obtained was placed inside a clean dried container. The average particle size of $0.835 \mathrm{~mm}$ was used.

Stock solutions of $1000 \mathrm{mg} / \mathrm{L}$ of the adsorbate (heavy metal ion) were prepared from the analytical grades of soluble salts of $\mathrm{Pb}\left(\mathrm{NO}_{3}\right)_{2}, \mathrm{Cu}\left(\mathrm{NO}_{3}\right)_{2}, \mathrm{Zn}\left(\mathrm{NO}_{3}\right)_{2}$ and $\mathrm{Cd}\left(\mathrm{NO}_{3}\right)_{2}$ which were accurately weighed and transferred into a known volumetric flask and serially diluted to obtain solutions between 10-100 $\mathrm{mg} / \mathrm{L}$. The experimental technique was carried out in a batch adsorption system.

$1 \mathrm{~g}$ of the adsorbent (clay) was added to each concentration between 10 to $100 \mathrm{mg} / \mathrm{L}$, the resulting solutions were shaken continuously and left till the next day. It was filtered into a clean dried empty conical flask and labeled accordingly. The filtrates were taken for analysis of the metals (adsorbate concentrations) using already calibrated atomic absorption spectrophotometer (AAS). AAS was well calibrated using standard solutions for each of the heavy metals. A linear graph passing through the origin with the $\mathrm{R}^{2}$ greater than $99.8 \%$ was obtained 
for each of the heavy metals.

$50 \mathrm{ml}$ solution was pipette from $100 \mathrm{mg} / \mathrm{L}$ into a conical flask followed by the dosage of different masses of the adsorbent between $1 \mathrm{~g}$ to $5 \mathrm{~g}$ and labeled accordingly. The resulting solutions were shaken continuously and left till the next day. Solutions were filtered into clean dried empty conical flasks and labeled accordingly. The filtrates collected in sample bottles were analysed by the use of AAS. The effect of time was studied by following the procedure using constant mass adsorbent and $100 \mathrm{ppm}$ solution of adsorbate. Minimum of five sets were set up and each experiment terminated at a specific time between 15-300 minutes. The clear filtrate obtained in each case was analyzed by using AAS.

The accuracy of the AAS analyses was assured by analyzing standard solutions. The concentrations were found to be 2.60, 2.01, 2.66 and $4.80 \%$ for $\mathrm{Pb}, \mathrm{Cu}, \mathrm{Zn}$ and $\mathrm{Cd}$ respectively. The amount of adsorbate adsorbed was calculated using the equation

$$
\begin{gathered}
\mathrm{C}_{\mathrm{ads}}=(\mathrm{Co}-\mathrm{Cs}) / \mathrm{M} \mathrm{mol} / \mathrm{dm}^{3} \mathrm{~g} \\
\mathrm{C}_{0}=\text { Initial concentration }\left(\mathrm{mol} / \mathrm{dm}^{3}\right. \\
\mathrm{C}_{\mathrm{s}} \quad=\text { Final concentration } \mathrm{mol} / \mathrm{dm}^{3} \\
\mathrm{M}=\text { Mass of adsorbent in gram }(\mathrm{g}) \\
\mathrm{Ca}_{\mathrm{ds}}=\mathrm{mol} / \mathrm{dm}^{3} / \mathrm{g} .
\end{gathered}
$$

\section{Results}

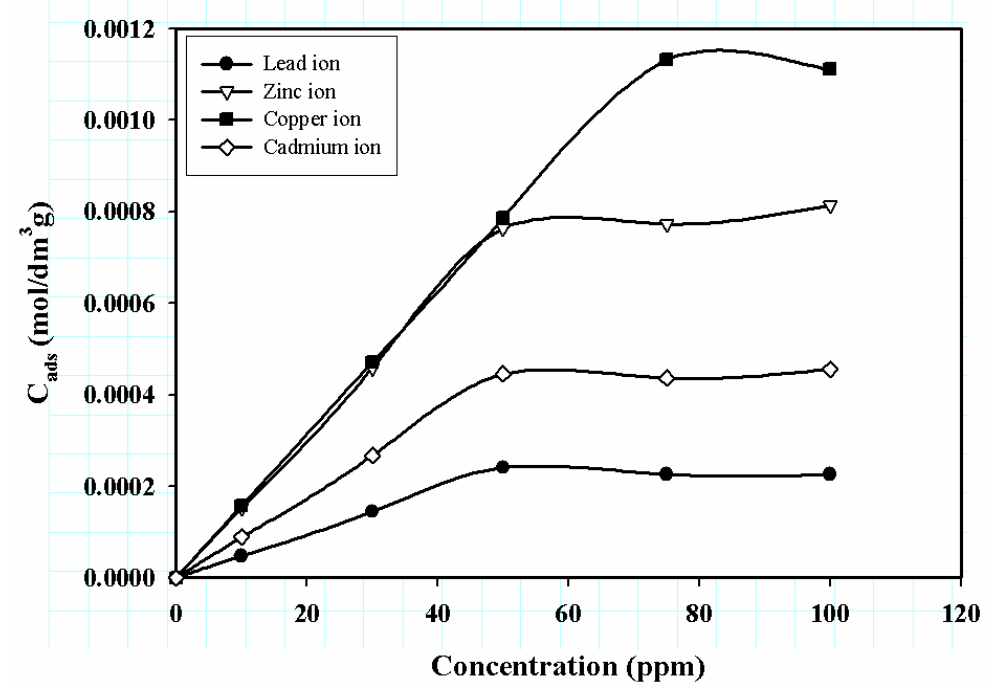

Figure 1. The influence of $\mathrm{C}_{\mathrm{ads}}$ against the concentration of the adsorbate.

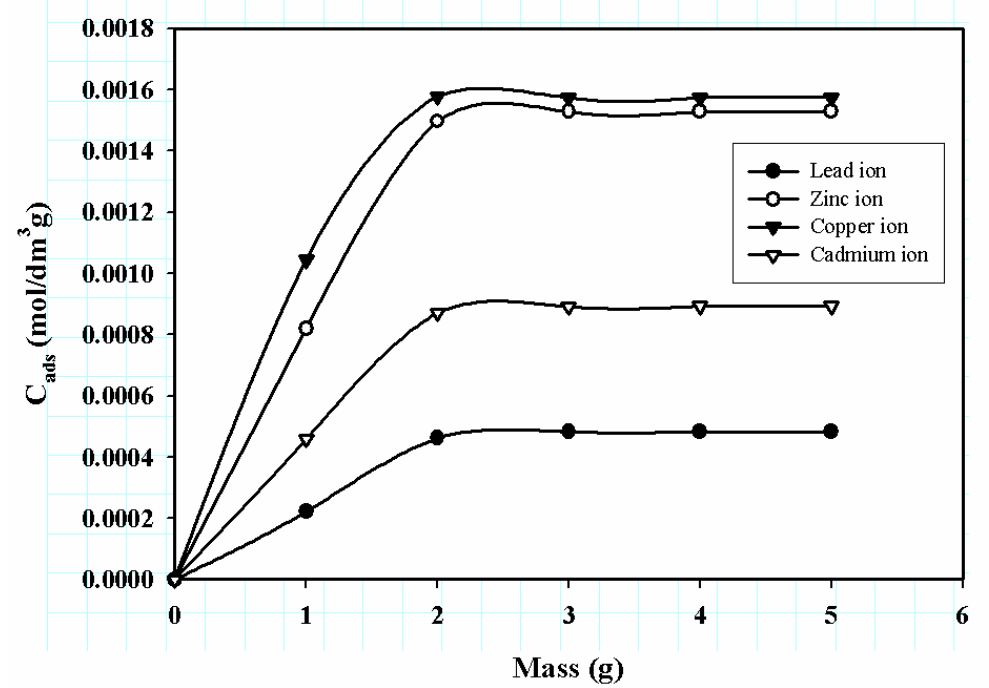

Figure 2. The effect of varied mass on the adsorption of the metal ions at constant adsorbate concentration. 


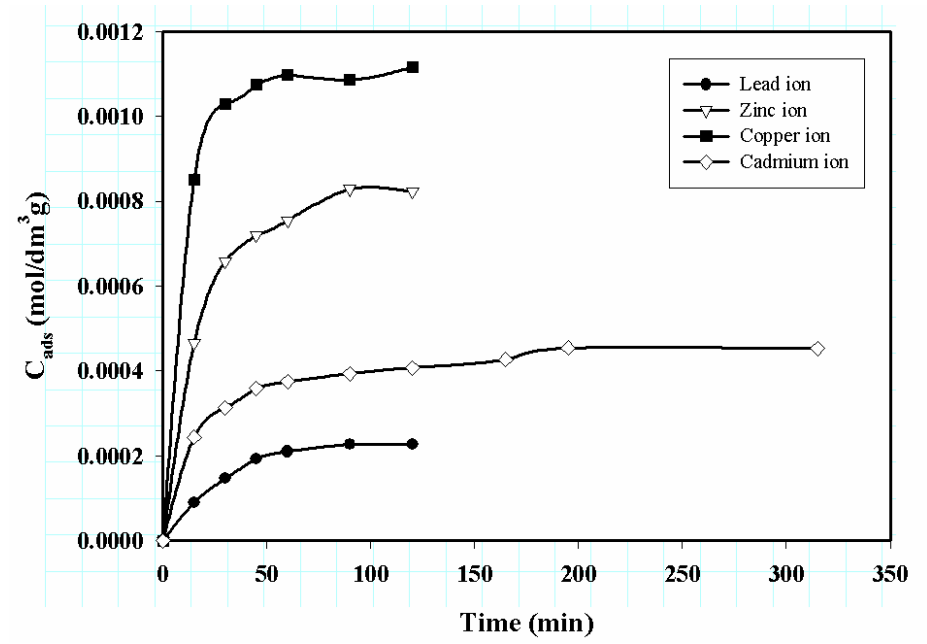

Figure 3. A plot of a relationship between $\mathrm{C}_{\text {ads }}$ and time.

Table 1. Freundlich and Langmuir isotherm's parameters obtained through the variation of concentrations of adsorbate

\begin{tabular}{lllllllllll}
\hline \multicolumn{2}{c}{ Freundlich } & \multicolumn{2}{c}{$\mathrm{V}_{\mathrm{ads}}=\mathrm{K}_{\mathrm{f}} \mathrm{C}_{\mathrm{eq}}{ }^{1 / \mathrm{n}}$} & & & Langmuir & $\mathrm{V}_{\mathrm{ads}}=\frac{V_{\max } K_{\mathrm{L}} C e q}{1+K_{L} C_{e q}}$ \\
\hline Absorbate & $\mathrm{K}_{\mathrm{f}} \times 10^{-5}$ & $\mathrm{n}$ & $\mathrm{R}^{2}$ & $\% \mathrm{DV}$ & $\mathrm{V}_{\max x} 10^{4}$ & $\mathrm{~K}_{\mathrm{L}} \times 10^{-3}$ & $\mathrm{R}^{2}$ & $\% \mathrm{DV}$ \\
\hline $\mathrm{Pb}(\mathrm{II})$ & 1.14 & 1.48 & 0.937 & 17.6 & 5.68 & 9.38 & 0.983 & 15.2 \\
$\mathrm{Cu}(\mathrm{II})$ & 2.13 & 1.11 & 0.978 & 9.90 & 4.49 & 3.63 & 0.998 & 5.80 \\
$\mathrm{Zn}(\mathrm{II})$ & 3.10 & 1.33 & 0.929 & 15.2 & 2.51 & 6.52 & 0.992 & 11.9 \\
$\mathrm{Cd}(\mathrm{II})$ & 1.90 & 1.36 & 0.910 & 16.2 & 1.35 & 7.11 & 0.990 & 15.2 \\
\hline
\end{tabular}

*Clays not the same

*Mean profile size $(0.2-0.3) \mathrm{mm}$

Table 2. Freundlich and Langmuir isotherm's parameters obtained through the variation of mass of adsorbate

\begin{tabular}{lllllllllll}
\multicolumn{2}{c}{ Freundlich } & \multicolumn{2}{c}{$\mathrm{V}_{\text {ads }}=\mathrm{K}_{\mathrm{f}} \mathrm{C}_{\mathrm{eq}}{ }^{1 / \mathrm{n}}$} & & & Langmuir & $\mathrm{V}_{\text {ads }}=\frac{V_{\max } K_{L} C e q}{1+K_{L} C_{e q}}$ \\
\hline Absorbate & $\mathrm{K}_{\mathrm{f}} \times 10^{-5}$ & $\mathrm{n}$ & $\mathrm{R}^{2}$ & $\% \mathrm{DV}$ & $\mathrm{V}_{\max } 10^{4}$ & $\mathrm{~K}_{\mathrm{L}} \times 10^{-3}$ & $\mathrm{R}^{2}$ & $\% \mathrm{DV}$ \\
\hline $\mathrm{Pb}(\mathrm{II})$ & 2.61 & 2.13 & 0.747 & 132 & 8.80 & 3.59 & 0.899 & 10.9 \\
$\mathrm{Cu}(\mathrm{II})$ & 1.14 & 4.05 & 0.759 & 7.14 & 1.95 & 1.23 & 0.909 & 3.73 \\
$\mathrm{Zn}(\mathrm{II})$ & 0.430 & 2.61 & 0.643 & 11.2 & 2.51 & 6.52 & 0.891 & 8.50 \\
$\mathrm{Cd}(\mathrm{II})$ & 5.29 & 2.29 & 0.740 & 11.8 & 1.41 & 0.520 & 0.890 & 7.58 \\
\hline
\end{tabular}

Table 3. Parameters from three different kinetic equations

\begin{tabular}{|c|c|c|c|c|c|c|c|c|c|c|c|c|}
\hline \multicolumn{4}{|c|}{ Power function } & \multicolumn{4}{|c|}{ Simple Elovich } & \multicolumn{4}{|c|}{ Olaofe proposed equation } & \\
\hline \multicolumn{5}{|c|}{ Cads $=a t^{b}$} & \multicolumn{3}{|c|}{ Cads $=C+d \operatorname{Int}$} & \multicolumn{2}{|c|}{ Cads } & $=\frac{K_{1} t}{1+K_{2} t}$ & & \\
\hline Absorbate & $\mathrm{ax} 10^{-4}$ & $\mathrm{~b}$ & $\mathrm{R}^{2}$ & $\% \mathrm{DEV}$ & $\mathrm{Cx} 10^{4}$ & $\mathrm{dx} 10^{4}$ & $\mathrm{R}^{2}$ & $\% \mathrm{DEV}$ & $\mathrm{K}_{1} \times 10^{6}$ & $\mathrm{~K}_{2} \times 10^{2}$ & $\mathrm{R}^{2}$ & $\% \mathrm{DEV}$ \\
\hline $\mathrm{Pb}(\mathrm{II})$ & 2.85 & 0.459 & 0.931 & 8.62 & 9.30 & 7.01 & 0.959 & 4.17 & 8.30 & 2.56 & 0.992 & 3.96 \\
\hline $\mathrm{Cu}(\mathrm{II})$ & 6.40 & 1.224 & 0.843 & 3.90 & 5.77 & 1.18 & 0.845 & 3.57 & 1.88 & 2.23 & 0.965 & 2.88 \\
\hline $\mathrm{Zn}(\mathrm{II})$ & 2.40 & 0.270 & 0.922 & 5.30 & 1.79 & 1.77 & 0.957 & 3.30 & 6.12 & 6.30 & 0.991 & 1.73 \\
\hline $\mathrm{Cd}(\mathrm{II})$ & 1.51 & 0.200 & 0.93 & 6.12 & 7.07 & 6.99 & 0.95 & 4.10 & 3.35 & 7.07 & 0.99 & 2.10 \\
\hline
\end{tabular}

\section{Discussion}

The results of the influence of $\left(\mathrm{C}_{\mathrm{ads}}\right)$ against the concentration of the adsorbate (metal ions) in $\mathrm{mg} / \mathrm{L}$ are shown in Fig 1. The curve reveals that adsorption of the clays steadily increases with increasing concentration of the metal ions to $50 \mathrm{ppm}$ for $\mathrm{Zn}$ (II), $\mathrm{Cd}(\mathrm{II})$ and $\mathrm{Pb}$ (II) ions except $\mathrm{Cu}$ (II) ions with steady increase in adsorption to $75 \mathrm{ppm}$. After these points, a flat profile was observed on all the clays, indicating that monolayer coverage of the clays has been achieved. It is likely that adsorption sites took up the available metal ions more quickly at lower concentrations due to more active sites than adsorbate. At higher metal ions concentrations, there would be likely 
greater adsorption in order to occupy the available adsorption sites. It is observed that in dilute solutions, equilibrium was probably reached faster than that of concentrated solutions. Similar observations have been reported by Magat Hanafiah , 2007) and Renugadevi et al; 2010) respectively.

However, Fig. 2 also presents the effect of varied masses of the clays on the rate of adsorption of the metal ions at constant adsorbate concentration. The curves obtained have shown that adsorption increases with increasing masses to $2 \mathrm{~g}$ before a plateau is observed. At $2 \mathrm{~g}$ of the clays and the given concentration $(100 \mathrm{mg} / \mathrm{L})$,indicating that there are more adsorbate than the number of active sites, However above $2 \mathrm{~g}$ of clay, a plateau is obtained in the curve, indicating that the adsorbents have adsorbed enough adsorbate on the available active sites .That is a monolayer coverage has been achieved.

It is obvious that the metal ions concentration left in solution decreases with increasing amount of adsorbent for a given initial metal concentration. This is so because increase in the amount of adsorbent provides greater surface areas or active sites for the adsorbate. The slower adsorption rate at the end is probably due to the saturation of active sites and attainment of equilibrium. Similar conclusions have been drawn by Asrari et al; 2010) and Renugadevi et al; 2010).

Fig. 3 shows graphically the relationship between $\mathrm{C}_{\text {ads }}$ and time. The curves explain that adsorption of metal ions on local clays increases with time. However there was a steady increase for the first 50 minutes. The removals of $\mathrm{Pb}$ (II) and $\mathrm{Zn}$ (II) ions were found to increase gradually on the clays when the adsorption time was varied from 10-300 minutes at a given concentration. This is because as time increases, the number of sites of the adsorbent filled by the adsorbate also increases. The increase in adsorption potentials with increase in contact time may be attributed to increase in mass transfer within the pores of the particles. For a longer time coupled with the small particle size used, the effect of inter mass diffusion would have been eliminated or reduced. Renugadevi et al; 2010) and Hengpeng et al; 2012) have reported similar trend or shape of curves for the adsorption of $\mathrm{Cr}(\mathrm{IV})$ and $\mathrm{Pb}$ (II) on activated carbon and modified rice husk respectively.

The present work has shown that Nigerian raw clays can be used to adsorb heavy metals from water to enhance its purity. Further processing of the clay would change the physical and chemical properties and would therefore probably improve its adsorption capacity.

\section{Mathematical model}

The present work has used two widely used adsorption isotherms to correlate the effect of adsorbate concentration or mass of adsorbent on the amount of adsorbate adsorbed. The two isotherms in their linear forms are:

Freundlich isotherm: $\operatorname{In} C_{\text {ads }}=\operatorname{In} K_{f}+\frac{1}{n} \operatorname{In} C_{e q}$

Langmuir isotherm: $\frac{1}{C_{a d s}}=\frac{1}{K_{L C} \max }\left(\frac{1}{C e q}\right)+\frac{1}{C_{\max }}$

Where $C_{\text {ads }}$ is the amount of adsorbate adsorbed at a given equilibrium concentration $C_{e q}$.

$K_{f}=$ Freundlich isotherms constant.

$\mathrm{n}=$ Constant

$K_{L}=$ Langmuir isotherm constant.

$C_{\text {max }}=$ Maximium amount of adsorbate that adsorbent can adsorbed.

The procured experimental data were fitted to the equations using linear regression.

The Table 1 presented the estimated parameters in the Freundlich and Langmuir isotherms using the data presented in Fig. 1.The values obtained for $\mathrm{K}_{\mathrm{f}}$ for different metal ions ranged between 1.14- 3.10x $10^{5}$ with $\mathrm{Zn}^{2+}$ having the highest value. The value of $\mathrm{n}$ varies between 1.11 and 1.48 , with lead having the highest values. The value of $\mathrm{R}^{2}$ varies between 91.0 to $97.8 \%$ showing that Freundlich isotherms have a good correlation of the gathered data.

Langmuir isotherm parameter $\mathrm{K}_{\mathrm{L}}$ varies between 3.63 to $9.38 \times 10^{-3}$. This shows that lead has the highest value indicating that it has the highest attraction to the clay, since $\mathrm{K}_{\mathrm{L}}$ is a measure of heat of adsorption. The maximum adsorption capacity (monolayer coverage) varied between 1.35 to $5.68 \times 10^{4} \mathrm{~mol} / \mathrm{dm}^{3} \mathrm{~g}$. Lead also had the highest monolayer coverage. The $\mathrm{R}^{2}$ values show that Langmuir adsorption isotherm had a better correlation that Freundlich adsorption isotherm. This is attested to by higher values of $\mathrm{R}^{2}$ for Langmuir adsorption isotherm compared with Freundlich adsorption isotherm.

The percentage deviation is given by: 


$$
\% D V=\Sigma\left(\frac{C_{\text {pred }}-C_{\text {obs }}}{C_{\text {obs }}}\right) \times \frac{100}{n}
$$

The $\%$ deviation was calculated and values presented in Table1. The two isotherms predicted the gathered data to a maximum accuracy of $17.6 \%$ and $15.2 \%$ for lead $(\mathrm{Pb})$ in Freundlich and Langmuir isotherms respectively. The percentage deviation also supports the earlier conclusion than Langmuir isotherm represents the collected data adequately than Freundlich isotherm because all the percentage deviations for Langmuir were smaller than that of Freundlich isotherm.

The adsorption kinetic data of heavy metals on clays are presented in Fig. 3 and were correlated by the following adsorption kinetic equations

(1) Power function:

(II) Simple Elovich

(III) Olaofe proposed equation (OPE)

$$
\begin{aligned}
& \mathrm{C}_{\mathrm{ads}}=\mathrm{at}^{\mathrm{b}} \\
& \text { Cads }=\mathrm{C}+\mathrm{dInK} \text { and }
\end{aligned}
$$

$$
\mathrm{C}_{\mathrm{ads}}=\frac{K_{1 t}}{1+K_{2} t} \text {. }
$$

The parameters $\left(\mathrm{a}, \mathrm{b}, \mathrm{c}, \mathrm{d}, \mathrm{k}_{1}\right.$ and $\mathrm{k}_{2}$ ) in the above equations were estimated using linear regression analysis .Table 3.presents the estimated of these constant parameters and other statistical parameters (R-squared and percentage deviation).The observed $\mathrm{R}^{2}$ and the percentage deviation showed that the three equations correlated the data. However, the power function had the least correlation with $\mathrm{R}^{2}$ between84-93\%. While Olaofe's proposed equation has the best correlation with $\mathrm{R}^{2}$ between 96 to $99 \%$.Based on $\mathrm{R}^{2}$ and \% deviation, the kinetic of $\mathrm{Cu}$ (II) ions adsorption on the clay soils was found to have the least correlation as it has $\mathrm{R}^{2} 84 \%$ and highest percentage deviation than the other heavy metals such as $\mathrm{Pb}$ (II), $\mathrm{Cd}$ (II) and $\mathrm{Zn}$ (II)that have highest values of $\mathrm{R}^{2}$ and lowest percentage deviation values. This is in agreement with other researchers' results which claimed that the simple Elovich equation was able to describe adequately the kinetics of $\mathrm{Cu}(\mathrm{II})$ adsorption an lignite and cashew nut shell (Gu and Ding,1996) and (Senthilkumar,2011) The order of satisfactory correlation for all the heavy metals of the clays and the estimated percentage deviation also confirms this order

$$
\mathrm{OPE}>\mathrm{SE}>\mathrm{PF} \text {. }
$$

It can be concluded that the kinetic of the heavy metals ( $\mathrm{Pb}(\mathrm{II}), \mathrm{Cu}(\mathrm{II}), \mathrm{Zn}$ (II) and $\mathrm{Cd}(\mathrm{II})$ ) can be satisfactorily fitted by Olaofe proposed equation. This is due to the fact that it has the highest $\mathrm{R}^{2}$ values; hence, it has better correlation and lowest \% deviation when compared with others. This is followed by simple Elovich equation which also confirms the work reported by Renugadevi et al; 2010, on the kinetic of Cr(VI) removal from aqueous solution by adsorption technique using activated carbon from pods of wood apple.

\section{Conclusion}

Clays have been found to be very effective adsorbents for the efficient removal of heavy metal ions from polluted water. The adsorption of heavy metal ions by clays has been shown to increase with increasing concentration or dosage and contact time at low values and reached a plateau at high values. The adsorption isotherm data were adequately fitted with Langmuir equation but has less fitting with Freundlich isotherm. $\mathrm{Pb}(\mathrm{II})$ has the highest monolayer coverage and $\mathrm{K}_{\mathrm{L}}$ value indicating greatest attraction to the clay. The adsorptive kinetics data were satisfactorily correlated with power function, simple Elovich and Olaofe's proposed equations using linear regression analysis. The Olaofe's proposed equation was found to have the best correlation with $\mathrm{R}^{2}$ between 96-99\% and the kinetics of $\mathrm{Cu}$ (II) adsorption on the local clays is the least when compared with other heavy metals. The present work has demonstrated that clay soils in Nigeria have the potential to be used as adsorbents for the removal of heavy metals from polluted water.

\section{References}

Abd El-Ghaffar, M. A., Abdel-Wahab, Z. H., \& Elwakeel, K. Z. (2012). Extraction and separation studies of silver(I) and copper(II) from their aqueous solution using chemically modified melamine resins. Journal of Hydrometallurgy, 96, 27-34. http://dx.doi.org/10.1016/j.hydromet.2008.07.008

Asrari, E., Tavallali, H., \& Hagshenus, M. (2010). Removal of $\mathrm{Zn}(\mathrm{II})$ and $\mathrm{Pb}(\mathrm{II})$ ions using rice husk ih food industrial waste water. Journal of Applied Science Environmental Management, 14(A), 159-162.

Babarinde, N. A. A. (2002). Adsorption of Zinc(II) and Cadmium(II) by coconut husk and goat hair. Journal of Pure and Applied Science, 5, 81-85.

Bhattacharyya, K. G., \& Gupta, S. S. (2008). Adsorption of a few heavy metals on natural and modified kaolinite and montmorillinite: A review. Advances in Colloid and Interface Science, 140, 114-131. 
http://dx.doi.org/10.1016/j.cis.2007.12.008

Chao-Yn, K. (2009). Water purification of removal of aqueous copper (II) by as grown and modified multi-walled carbon nanotubes. Journal of Desalitation, 2, 781-785.

Coelho, T. C., de Favere, V. T., Laus, R., Laranjeira, C., \& Mangrich, A. S. (2001). Reactive and Functional Polymers, 67, 468-475. http://dx.doi.org/10.1016/j.reactfunctpolym.2007.02.009

Eloussoief, M., \& Benzina, M. (2012). Efficiency of natural and acid-naturated clays in the removal of $\mathrm{Pb}(\mathrm{II})$ from aqueous solution. Journal of Hazard matter, 178, 753-757. http://dx.doi.org/10.1016/j.jhazmat.2010.02.004

Gode, F., \& Pelalivan, E. (2006). Removal of chromium (III) from aqueous solutions using Lewatit S.100:The effect of $\mathrm{pH}$, time, metal concentration and temperature. Journal of hazard matter, 136, 330-337. http://dx.doi.org/10.1016/j.jhazmat.2005.12.021

Guggenhein, S., \& Martin, R. (1995). Defination of Clay and clay minerals. Report of the AIPETA nomenclature and CMS nomenclature committees.

Gu, J. M, \& Ding, D. R. (1996). A study on the characteristics of adsorption for $\mathrm{Zn}^{2+}, \mathrm{Cu}^{2+}, \mathrm{Pb}^{2+}$ ions onto peat and lignite. Journal of Environmental Chemistry, 15, 343-346.

Henypeng, Y., Zhang, L., Zhang, B., Wu, G., \& Du, D. (2012). Adsorptive removal of $\mathrm{Cu}(\mathrm{II})$ from aqueous solution using modified rice husk. International Journal of Engineering Research and Application, 2, 855-863.

Hiller, S., Middleton, G. U., Church, N. J., \& Coniglio, M. (2003). Clay mineralogy Encyclopedia of sediments and sedimentary rocks. Kluwer Academic Publishers.

Megat, Hanafiat, M.A.K., Yahya, M. Z. A, Zakara, H., \& Ibrahim, S. C. (2007). Adsorption of Cd(II) ions from aqueous solutions by Lalang ( Imperata cylindrical) leaf powder: Effect of physicochemical environmental. Journal of Applied Sciences, 7(4), 489-493. http://dx.doi.org/10.3923/jas.2007.489.493

Maranon, E., \& Sastre, H. (1999). Heavy metal removal in packed beds using apple wastes. Journal of Bioresources Technology, 28, 39-43.

Olaofe, O., \& Bosch, H. (1980). The production and characterization of activated carbon from carboneous materials. Journal of Chemical Age of India, 213(3), 238-242.

Qrhan, Y., \& Buyukgungor, H. (1993). The removal of heavy metals by using agricultural wastes. Water Science and Technology, 28, 247-255.

Renugadevi, N., Sreeja, M., \& Lalitha, P. (2010). Kinetics of chromium(IV) removal from aqueous solution by adsorption technique using activated carbon from pods of wood apple. Journal of Ultra Chemistry, 6(1), 27-34.

Saikia, D. K., Mathur, R. P., \& Srivastava, S. K. (1987). Adsorption of copper, zinc and lead by lead bed sediments of river Ganges in India. Journal Environmental Technology Letters, 8, 149-152. http://dx.doi.org/10.1080/09593338709384473

Scarre, C. (2005). The human past. Thames and Hudson. London 238.

Senthlkumar, P., Ramalingan, V., Sathyaselvabala, S., Dinesh Kirupha, S., \& Sivanesan, S. (2011). Removal of copper (II) ions from aqueous solution by adsorption using cashew nut and shell. Journal of Desalination, 266(1-3), 63-71. http://dx.doi.org/10.1016/j.desal.2010.08.003

Wilczak, A., \& Keinath, T. M. (1993). Kinetics of sorption desorption of copper(II) and lead(II) on activated carbon. Journal of Environment Resources, 63, 238-244.

Yu, M. H. (2005). Environmental Toxicology-Biological and Health Effects of pollutants. $2^{\text {nd }}$.ed. CRC. Press Boca Raton, London.

\section{Copyrights}

Copyright for this article is retained by the author(s), with first publication rights granted to the journal.

This is an open-access article distributed under the terms and conditions of the Creative Commons Attribution license (http://creativecommons.org/licenses/by/3.0/). 